\title{
MAINE GROUND-WATER QUALITY
}

\author{
By T.J. Maloney, U.S. Geological Survey
}

Crystalline Bedrock part of Background Water Quality Section

By E.M. Lanctot, Maine Department of Human Services

U.S. Geological Survey Open-File Report 87-0729 


\section{DEPARTMENT OF THE INTERIOR \\ DONALD PAUL HODEL, Secretary}

\section{U.S. GEOLOGICAL SURVEY}

Dallas L. Peck, Director

For additional information:

Chief Hydrologist

U.S. Geological Survey

407 National Center

Reston, VA 22092

\section{For sale by:}

U.S. Geological Survey

Books and Open-File Reports Section Federal Center

Box 25425

Denver, Colorado 80225

Use of trade names in this report is for descriptive purposes only and does not constitute endorsement by the U.S. Geological Survey 


\section{FOREWORD}

This report contains summary information on ground-water quality in one of the $\mathbf{5 0}$ States, Puerto Rico, the Virgin Islands, or the Trust Territories of the Pacific Islands, Saipan, Guam, and American Samoa. The material is extracted from the manuscript of the 1986 National Water Summary, and with the exception of the illustrations, which will be reproduced in multi-color in the 1986 National Water Summary, the format and content of this report is identical to the State ground-water-quality descriptions to be published in the 1986 National Water Summary. Release of this information before formal publication in the 1986 National Water Summary permits the earliest access by the public. 


\section{Contents}

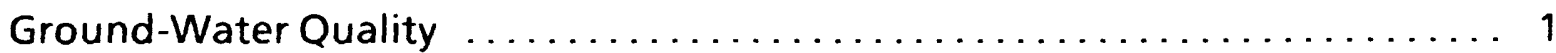

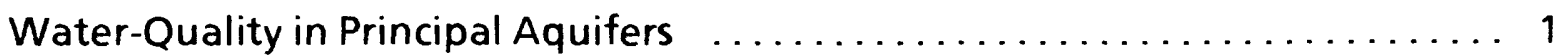

Background Water Quality $\ldots \ldots \ldots \ldots \ldots \ldots \ldots \ldots \ldots \ldots \ldots \ldots \ldots \ldots$

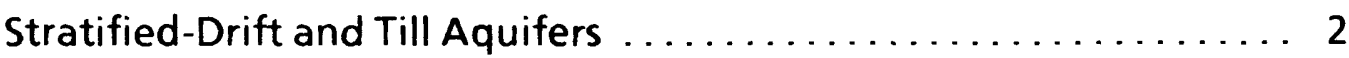

Carbonate Bedrock Aquifer $\ldots \ldots \ldots \ldots \ldots \ldots \ldots \ldots \ldots \ldots \ldots \ldots$

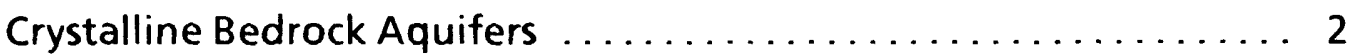

Effects of Land Use on Water Quality $\ldots \ldots \ldots \ldots \ldots \ldots \ldots \ldots \ldots \ldots$

Urbanization ................................... 3

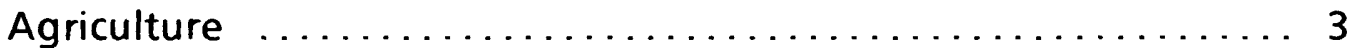

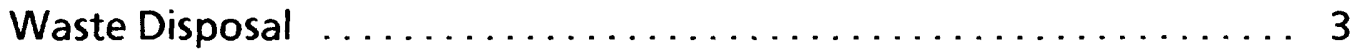

Potential for Water-Quality Changes $\ldots \ldots \ldots \ldots \ldots \ldots \ldots \ldots \ldots$

Ground-Water-Quality Management ....................... 4

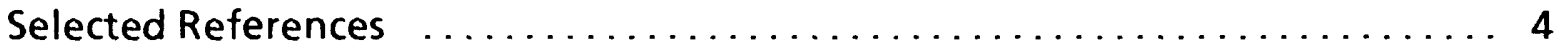

Illustrations

Figure 1.--Selected geographic feature and 1985 population distribution in Maine.

Figure 2.--Principal aquifers and related water-quality data in Maine. 7

Figure 3.--Selected waste sites and ground-water quality information in Maine.

Figure 4.--Median radon concentration in water from bedrock and geographic distribution of bedrock types in Maine. 


\section{MAINE Ground-Water Quality}

The ground-water resources of Maine are used to supply 57 percent of the State's population. The population is concentrated largely in the southwestern quarter of the State (fig. 1). Water quality in the State's aquifers (fig. 2) is generally excellent and suitable for most uses, but water use in some areas is limited by excessive hardness or naturally occurring large concentrations of iron, manganese, sulfur, sodium chloride, and radon. Water quality in several areas has been degraded by urbanization, agriculture, and industrial- and municipal-waste disposal (fig.3).

Ground-water quality has been monitored since 1968 as part of a cooperative program between the U.S. Geological Survey and the State. This program provides information on background levels of inorganic constituents and total organic carbon. State agencies and private industry have sampled for organic compounds at specific sites where hazardous-waste contamination is suspected. In 1985, Maine instituted a 3-year program to determine the effect of pesticide use on the State's ground-water supplies.

Each of the aquifers is vulnerable to contamination, but the stratified-drift and bedrock aquifers tend to be the most severely effected. The large permeability of the stratified-drift aquifers allows contaminants to percolate readily from land surface to the water table (Tolman and others, 1983). Pollutants that reach the bedrock aquifers can travel along secondary openings such as cleavage and bedding planes, joints, fractures and solution openings, and contaminate the aquifer over a large area.

The Maine Department of Environmental Protection (MDEP) has identified 32 hazardous-waste sites that threaten ground-water quality (fig. 3). Eighteen of these sites require monitoring under the Federal Resource Conservation and Recovery Act (RCRA) of 1976. Five sites have been identified as Superfund sites in the National Priorities List (NPL) of the U.S. Environmental Protection Agency (1986c). These sites receive additional evaluation under the Comprehensive Environmental Response, Compensation, and Liability Act (CERCLA) of 1980. The MDEP is evaluating the remaining nine sites under the Maine Hazardous Waste Fund and Uncontrolled Substance Act. The types of waste generators in this group of nine sites include metal finishing, chemical and photochemical companies, salvage operations, and military installations. Groundwater contamination is suspected at many other sites and these sites will be included in the State's program if evidence of contamination becomes available. Contamination of ground water is documented at six of the RCRA sites, two of the CERCLA sites, and eight of the State program sites. At the remaining 16 sites, either no contamination has been detected or monitoring data have not been evaluated. In addition, the U.S. Department of Defense (DOD) has identified one site at one facility where contamination has warranted remedial action.

\section{WATER QUALITY IN PRINCIPAL AQUIFERS}

Maine has four principal types of aquifers (fig. 2)-stratified drift (glaciofluvial deposits), till, carbonate rock, and metamorphic and igneous crystalline bedrock (U.S. Geological Survey, 1985, p. 237-240). The areal extent of each aquifer type, except till, is shown in figure $2 A$ and the typical stratigraphic sequence is shown by the block diagram, figure $2 B$. Till forms a discontinuous cover over bedrock in upland areas, and, in valleys, it is usually located between stratified-drift deposits and bedrock. Thick, stratified-drift (ice-contact) sand and gravel is located along some valley walls as kame deposits or as eskers in the center of valleys. Silts and clays deposited in marine or lacustrine environments usually is interspersed with the coarse sand and gravel.

The chemical quality of ground water is determined by several natural factors. In the stratified-drift and till aquifers the primary control is the chemical composition of the sand and gravel and associated marine clay. Most of the sand and gravel is derived from noncalcareous, crystalline bedrock, which generally consists of silicate minerals that are relatively insoluble. Ground water in regions with this type of bedrock tends to have a small dissolvedsolids concentration compared to water in regions with carbonate bedrock. Chemical reactions that occur as infiltrating water passes through the soil zone can also affect ground-water chemistry. Where the saturated thickness is great, the flow paths are long and the water may have a long time to dissolve soluble material in the aquifer (Caswell, 1978). The chemistry of precipitation can also affect ground-water quality. In coastal regions where precipitation contains sea salt, the concentrations of sodium and chloride in ground water are typically larger than in inland areas. Elevated concentrations of sodium and chloride can also result from saltwater intrusion in coastal areas or from the entrapment of seawater in regions of relatively stagnant ground-water flow, which occurred during the late Wisconsinan marine submergence (Tepper, 1980).

Public suppliers that use ground water as a source serve about 12 percent of the population. These suppliers rely almost exclusively on large-yield screened wells located in stratified-drift aquifers. A few large-yield-greater than $200 \mathrm{gal} / \mathrm{min}$ (gallons per minute)supply wells are located in bedrock aquifers.

About 45 percent of the population obtains water from individual private wells. All four aquifer types can yield sufficient quantities of water ( $2 \mathrm{gal} / \mathrm{min}$ ) for individual households. The quality of water from each of the aquifers generally is suitable for most uses, but increased concentrations of some constituents can limit use.

\section{BACKGROUND WATER QUALITY}

A graphic summary of selected water-quality variables compiled from the U.S. Geological Survey's National Water Data Storage and Retrieval System (WATSTORE) is presented in figure $2 C$. The summary is based on dissolved-solids, hardness (as calcium carbonate), sodium, nitrate (as nitrogen), iron, and manganese analyses of water samples collected from 1960 to 1985 from the four principal aquifer types in Maine. Percentiles of these variables are compared to national standards that specify the maximum concentration or level of a contaminant in a drinking-water supply as established by the U.S. Environmental Protection Agency (1986a,b). The primary contaminant level standards are health related and are legally enforceable. The secondary maximum contaminant level standards apply to esthetic qualities and are recommended guidelines. The primary drinking-water standards include a maximum concentration of $10 \mathrm{mg} / \mathrm{L}$ (milligrams per liter) nitrate (as nitrogen), and the secondary drinking-water standards include maximum concentrations of $500 \mathrm{mg} / \mathrm{L}$ dissolved solids, $300 \mu \mathrm{g} / \mathrm{L}$ (micrograms per liter) iron, and $50 \mu \mathrm{g} / \mathrm{L}$ manganese. Although a national maximum concentration level for sodium has not been set by the U.S. Environmental Protection Agency (EPA), a concentration smaller than $20 \mathrm{mg} / \mathrm{L}$ is recommended for people on sodium restricted diets (U.S. Environmental Protection Agency, 1976). The "very hard" classification of hardness $(180 \mathrm{mg} / \mathrm{L}$ as calcium carbonate) as defined by Durfor and Becker $(1964$, p. 27) is used as the upper limit for general water use. 


\section{Stratified-Drift and Till Aquifers}

The water-quality characteristics of the stratified-drift and till aquifer types are similar, as shown in figure $2 C$. Water from the aquifers typically had small concentrations of dissolved solids and was soft. The median dissolved-solids concentrations for water from the stratified-drift and till aquifer types are 80 and $90 \mathrm{mg} / \mathrm{L}$, respectively. Likewise, the median hardness concentrations (as calcium carbonate) for water from the stratified-drift and till aquifer types were 35 and $50 \mathrm{mg} / \mathrm{L}$, respectively. The 90 th-percentile concentration of dissolved solids does not exceed the national drinkingwater standard in either aquifer (fig. $2 C$ ).

Median concentrations of naturally occurring sodium in water in the stratified-drift and till aquifers are small, 4.9 and $6.1 \mathrm{mg} / \mathrm{L}$, respectively. Although the median background concentrations in water in both aquifers did not exceed health advisory levels, these aquifer types are particularly susceptible to sodium contamination from storage and application of road deicing salt. Another source of sodium contamination is from saltwater intrusion induced by overpumping of an aquifer in coastal areas.

Background concentrations of nitrate (as nitrogen) were small, with median concentrations of 0.18 and $0.36 \mathrm{mg} / \mathrm{L}$ in the stratified-drift and till aquifers, respectively. The 90th-percentile concentrations in these two aquifers are less than one-half the national maximum standard of $10 \mathrm{mg} / \mathrm{L}$ (fig. $2 C$ ). Drainage from barnyards or septic tanks is a source of nitrate contamination, which can severely degrade water quality.

Concentrations of iron and manganese in more than 25 percent of the analyses of water from the stratified-drift and till aquifers (fig. $2 C$ ) exceed drinking-water standards 300 and $50 \mu \mathrm{g} / \mathrm{L}$, respectively. These metals are the products of weathering of minerals and dissolution of oxide coatings on aquifer materials. They are easily dissolved in acidic water in the absence of oxygen. Water in the stratified drift is almost always acidic, but commonly contains enough dissolved oxygen to inhibit the solution of iron and manganese. However, ground water may lose some of its dissolved oxygen as it passes through organic deposits, such as peat or riverbottom sediments, and begin to dissolve and mobilize iron and manganese. Wells that initially yield water with small concentrations of these metals may yield water with larger concentrations and become less efficient as ground-water gradients are reversed by pumping, causing iron- and manganese-bearing water to flow to the well (Gay and Frimpter, 1985).

\section{Carbonate-Bedrock Aquifer}

The carbonate-bedrock aquifer types are limestone, calcareous shale, and calcareous siltstone deposits located primarily in the northeastern corner of the State in Aroostook County. The Carys Mills Formation-a bluish-gray limestone-is fairly widespread and constitutes the principal carbonate aquifer. Recoverable water is contained primarily in secondary openings, such as bedding planes, joints, fractures, and solution openings. Most wells completed in the carbonate aquifers are for domestic or farm use; however, some large-yielding wells $(500 \mathrm{gal} / \mathrm{min})$ have been developed for industry, public supply, and irrigation.

The quality of water in the carbonate aquifers is suitable for most uses. The few available samples indicate that the water had a moderately large dissolved-solids concentration and was very hard. The median concentrations were $256 \mathrm{mg} / \mathrm{L}$ dissolved solids and 204 $\mathrm{mg} / \mathrm{L}$ (as calcium carbonate) hardness. Concentrations of sodium (four analyses) range from $4.4 \mathrm{mg} / \mathrm{L}$ to $9.2 \mathrm{mg} / \mathrm{L}$.

\section{Crystalline-Bedrock Aquifers}

The crystalline-bedrock aquifer in Maine consists of a variety of igneous and metamorphic rocks. Igneous rocks include granite, gabbro, diorite, granodiorite, and pegmatite; metamorphic rocks include schist, gneiss, quartzite, slate, and argillite. These rocks are dense and relatively impermeable, but contain recoverable water in secondary openings such as joints, fractures, and bedding or cleavage planes. These aquifers are an important source of water for many rural domestic water users in Maine, and provide public supplies in some areas where other supplies are limited. Communities located on islands and peninsulas along Maine's coast often must depend on bedrock aquifers for water supplies.

Water in crystalline-bedrock aquifers was suitable for most uses. It had small concentrations of dissolved solids, with a median hardness of $119 \mathrm{mg} / \mathrm{L}$, and was moderately hard, with a median hardness of $73 \mathrm{mg} / \mathrm{L}$ (as calcium carbonate). The median concentration of sodium is small, $8.8 \mathrm{mg} / \mathrm{L}$, but was the largest for water from any of the four aquifer types. Increased sodium concentrations have been observed when the recharge zones of these aquifers are contaminated by deicing salts. Some wells drilled in coastal zones yicld brackish or salty water (Prescott, 1973; Tepper, 1980). Nitrate concentrations in water from crystalline bedrock are typically small, with a median concentration of $0.24 \mathrm{mg} / \mathrm{L}$. Water from some recharge areas that receive drainage from barnyards or septic fields has nitrate concentrations that exceed the drinking-water standard of $10 \mathrm{mg} / \mathrm{L}$. The median concentrations for iron and manganese are 62 and $11 \mathrm{mg} / \mathrm{L}$, respectively. The concentrations of iron and manganese in ground water from many localities statewide far exceed the drinking-water standards, thus requiring treatment prior to use.

Radon-222 in ground water has been recognized as a problem in Maine since the late 1950's. Several studies have been undertaken to determine the magnitude of the problem. Radon-222 is a radioactive-decay product of uranium. It is a colorless, odorless, inert gas and has been associated with the incidence of lung cancer among metal-ore miners (National Council on Radiation Protection and Measurements, 1984). One important source of radon in Maine is well water from crystalline bedrock. When this water is heated and agitated, as in a shower or dishwasher, the radon is released into the air where it becomes a health risk. A second source is "soil gas" - a mixture of vapors and gases including radon. Highpermeability soils, such as sand and gravel, facilitate migration of radon. Because radon does not combine chemically with other elements, it can migrate to the ground surface and seep into homes through cracks, pore spaces, and utility openings in basements.

Analysis of data collected by the University of Maine at Orono (Penobscot County) indicates that radon levels in ground water increase with increasing depth of bedrock wells and decrease with increasing yield (Hess and others, 1979). On the average, radon levels in water from wells completed in sand and gravel, unless capped by clay, did not exceed the Maine Department of Human Services' (MDHs) suggested limit of $20,000 \mathrm{pCi} / \mathrm{L}$ (picocuries per liter).

In Maine, the greatest levels of radon have been found in water punped from igneous plutons, which contain water with a median radon level of $6,550 \mathrm{pCi} / \mathrm{L}$. Water from granites containing the micas muscovite and biotite have especially large radon levels. Increased radon levels also have been found in high-grade metamorphic rock. The median concentrations of radon in water obtained from wells drilled into various rock types in Maine and the areal distribution of these rocks are shown in figure 4. Data used to produce this map came from files of the Maine Geological Survey and Maine Department of Human Services.

The health risks associated with the radon levels commonly found in homes are a subject of debate. The EPA recommends that remedial action be taken when indoor-air radon levels reach $4 \mathrm{pCi} / \mathrm{L}$ (U.S. Environmental Protection Agency, 1986e). Based on extrapolation from mining data, a person who lives in his home for 70 years and was exposed to $4 \mathrm{pCi} / \mathrm{L}$ for 75 percent of the time, faces an increased risk of lung cancer of from 1 to 5 chances in 
100. Aerators and carbon filters are highly effective in removing radon from water and various ventilation techniques have been used to remove radon from indoor air (U.S. Environmental Protection Agency and U.S. Department of Health and Human Services, 1986).

\section{EFFECTS OF LAND USE ON WATER QUALITY}

Ground-water quality has deteriorated in some areas because of the effects of urbanization, agriculture, and waste disposal. State agencies have instituted programs to determine the extent of contamination from these factors and to remedy situations that threaten the public health.

\section{Urbanization}

Three factors responsible for contamination of the greatest number of wells (fig. $3 B$ ) are highway-deicing chemicals, petroleum or heating oil from leaking underground storage tanks, and underground waste disposal through septic systems. The number of wells abandoned as a result of contamination from leakage of stored fuel has increased sharply during the past 10 years. Reports of contamination caused by deicing compounds and septic systems have remained fairly constant during the same period.

Well contamination by deicing salts has resulted from storage and spreading procedures. During the $1984-86$ period, 16 claims were settled by the Maine Department of Transportation (MDOT) that concerned salt contamination of wells resulting from MDOT operations. Of the 16 claims, 14 were attributed to contamination from storage facilities (A.C. Olson, Maine Department of Transportation, written commun., 1986).

In Maine, the general practice for operation of a salt-storage facility has been to place an uncovered salt pile at the location of a readily accessible sand supply, so that the materials could be mixed before spreading. This practice has two major drawbacks. First, many supplies of sand are parts of or are recharge areas for the largely permeable stratified-drift aquifers. Second, because the salt piles are uncovered, rain dissolves some of the salt, and the contaminated water then enters the underlying aquifer. The MDEP, Bureau of Water Quality Control, has examined each of the 800 registered salt-storage sites in the State to determine their effects on water quality and to prioritize construction of covered shelters. Well contamination has been documented at about 50 of the sites (D.L. Locke, Maine Department of Environmental Protection, oral commun., 1986).

Salt-spreading procedures typically are responsible for contamination of wells located near highways. Maine law 23 MRSA (Maine Revised Statute Annotated) 652 provides that no well can be located within the public right-of-way. As a further measure to prevent contamination from salt spreading procedures, it is recommended that wells be constructed at least 50 feet from the edge of highway pavement (A.C. Olson, Maine Department of Transportation, oral commun., 1986). The quantity of salt spread by the MDOT has been greatly decreased from 110,000 tons in 1968 to 60,000 tons in 1986 (J.E. Dority, Maine Department of Transportation, oral commun., 1986).

Contamination of ground water by leaking underground petroleum-storage tanks has been documented in 215 wells statewide, and many more wells that have been contaminated water may exist but have not been reported (Scudder and Anderson, 1986). Towns with six or more wells that have been contaminated by petroleum are Boothbay (Lincoln County), Easton (Aroostook County), Friendship (Knox County), Lee (Penobscot County), North Berwick (York County), Penobscot (Hancock County), Readfield (Kennebec County), and Waterboro (York County). When tank leaks develop, they may go undetected for years, while the tank continues to be used or after a partly filled tank has been abandoned. The locations of many abandoned tanks are not known. The
1986 MDEP tank-registration files show more than 20,000 tanks statewide. The petroleum industry estimates that 20 to 40 percent of these tanks may be leaking (Garrett, 1986). The amount of product leaking to ground water statewide is estimated to be 6 million gallons per year (Moreau, 1983).

About 250,000 housing units in Maine use septic systems for waste disposal (D.C. Hoxie, Maine Department of Human Services, oral commun., 1986). Even a properly designed system can contribute some contaminants, such as nitrates, chlorides, bacteria, metals, and solvents, to ground water, (Garrett, 1986). In 1974, a more stringent State Plumbing Code was implemented that required use of soil-horizon information in the design of septic systems. This code has resulted in improved function and efficiency of the systems and has helped curb ground-water contamination (D.C. Hoxie, oral commun., 1986).

\section{Agriculture}

The use of insecticides and herbicides in Maine's agriculture has raised concern about adverse effects on ground water. The National Governors Association (1985) reports restricted use of water from 30 wells in Aroostook and Penobscot Counties resulting from pesticide contamination. In 1985, the State began a 3-year statewide program to determine concentrations of pesticides and herbicides in ground water, to document the extent of contamination, and to assess the health risks of drinking the contaminated water. During the first year of this investigation, detectable concentrations of pesticides were not observed; however, the results were considered inconclusive because of questions regarding sample-collection and analytical techniques (Tolman, 1986).

Manure storage and spreading and application of commercial fertilizers are agricultural practices that can contaminate ground water with nitrates. The Maine Department of Agriculture, Food and Rural Resources, has determined that there are 3,000 cattle farms that annually produce 1.7 million tons of manure, and 1,700 poultry farms that produce 0.4 million ton of manure. As part of the pesticide and herbicide test program mentioned above, samples have been collected to determine the extent of nitrate ground-water contamination. One-quarter of the wells sampled during the first year of the monitoring program had nitrate concentrations that exceeded the drinking-water standard of $10 \mathrm{mg} / \mathrm{L}$ (as nitrogen) (Tolman, 1986).

\section{Waste Disposal}

A variety of industries in Maine, including shipbuilding, munitions, photo-chemicals, tanneries, plastics, electronics, and metal finishing, generate hazardous waste. Types of chemicals involved include trace metals, polychlorinated biphenyls, trichloroethylene, and other volatile organics. Many industries have developed their own waste-disposal sites (Garrett, 1986). Military installations in Limestone (Aroostook County), Brunswick (Cumberland County), and Kittery (York County) also have wastedisposal sites that have resulted from their operations.

The paper industry in Maine disposes of waste at eight sites, which are included on the RCRA list. Caustics and acids are used extensively by the paper industry, but no ground-water contamination has been documented at any of these locations.

Most of the 32 hazardous-waste sites MDEP has identified are located in the populous areas of southern and central Maine (fig. $3 A$ ). Ground-water contamination has been documented at 16 of these sites. Of the 36 drinking-water wells contaminated by these sites, 34 are attributed to two CERCLA sites in Gray (Cumberland County) and in Winthrop (Kennebeck County).

Also, as of September 1985, 28 hazardous-waste sites at 4 facilities in Maine have been identified by the DOD as part of their Installation Restoration Program (IRP) as having potential for con- 
tamination. The IRP, established in 1976, parallels the EPA Superfund program under CERCLA. The EPA presently ranks these sites under the hazardous ranking system and may include them in the NPL. Of the 28 sites evaluated under the program only one site at one facility (fig. $3 A$ ) was considered to present a hazard significant enough to warrant response action in accordance with CERCLA. The remaining sites were scheduled for confirmation studies to determine if remedial action is required.

In addition to the hazardous-waste sites, the MDEP, Bureau of Land Quality Control, has identified 379 active and inactive municipal-landfill sites. The locations are known for 371 of these sites (fig. $3 C$ ); 114 of these landfills overlie stratified-drift deposits. These typically are conventional landfills that may allow leachate to percolate to the water table. Salt and hazardous-waste compounds are common in landfill leachate (Garrett, 1986). Of the 379 sites, 270 are active. Many municipalities are becoming members of waste-to-energy projects, and an additional 125 towns are expected to close existing landfills. The volume of solid waste will be greatly reduced by waste-to-energy projects; however, the substantial quantities of ash generated need to be placed in a secure landfill, one which has an impervious liner and a collection system so that the leachate can be recovered and treated.

\section{Potential For WATER-Quality Changes}

The potential for water-quality changes is greatest in highpopulation-growth areas, including southern Maine, resort areas, and the corridor along Interstate 95 from Portland to Bangor. Increased pumping to meet the demands of the growing population may change ground-water flow patterns, increase the concentrations of iron and manganese, or cause saltwater intrusion in coastal areas. The increased population also is expected to cause additional contamination as a result of urbanization effects.

The number of wells contaminated by leaking underground petroleum-storage tanks is expected to increase steadily until existing petroleum facilities are replaced, using proper installation and handling practices.

\section{GROUND-WATER-QUALITY MANAGEMENT}

Management of ground-water quality in Maine is shared by several State agencies with statutory responsibility. The MDEP reviews and licenses land-use activities that affect ground water. The Department also conducts research into effects of petroleum leaks and contamination from highway-deicing compounds on ground water, provides ground-water-quality assessments, investigates sites of spills, and provides emergency response and cleanup services.

The Maine Department of Human Services is responsible for ground-water-quality management through its Drinking Water Program, Environmental Health Unit, and Public Health Laboratories. The Department reviews and approves new public water-supply sources, monitors the quality of existing sources, does research on ground-water-transmitted diseases, and analyzes private water supplies, including determination of petroleum contamination. It also is active in determining the health risks associated with radon.

The Maine Department of Conservation, through the Maine Geological Survey and the Land Use Regulation Commission, coordinates ground-water research, performs research into permit-related ground-water problems, and regulates activities that impact ground water in areas of sparse population. The Department also coordinates a statewide ground-water-quality sampling network and conducts a program to determine the affects of pesticide use on ground water--

The "Maine Ground Water Policy"' was issued June 1985, by executive order of the Governor. This order states: "It is the policy of the State of Maine to allocate, protect, and monitor Maine's ground-water resources, through measures which expand our knowledge of ground water hydrogeology, protect public and environmental health, meet future water supply needs, and encourage a sound economy." The Maine Land and Water Resources Council of the State Planning Office was given responsibility to oversee implementation of the policy through formation of a Ground Water Standing Committee. The committee is chaired by the Commissioner of the MDEP and has representatives from other member agencies of the Land and Water Resources Council. The committee's day-to-day activities are carried out by the State Groundwater Coordinator at the State Planning Office. The coordinator serves as a ground-water consultant to the State; provides a State focus for communication on ground-water issues with Federal agencies, local governments, regional planning agencies, and the public; assesses State ground-water priorities; assures cost-effective allocation of State funding and staffing resources; and coordinates the efforts of the Ground Water Standing Committee member agencies.

Six subcommittees of the Ground Water Standing Committee were established to focus on the ground-water issues of Resource Use, Resource Protection, Groundwater Classification, Health Risk Assessment, Interagency Coordination, and Ground Water Education. The subcommittees made their reports and recommendations on July 1, 1986. A Ground-Water Policy Subcommittee has been formed to set priorities and review allocation of resources. Many of the recommendations have been implemented, and pilot projects in ground-water data management and ground-water classification have been undertaken. Other recommendations, such as protection for essential public and private ground-water supplies, requiring a well-information report for new wells, salt-storage site regulations, and regulations for petroleum tank installation, operation, and abandonment, will require legislation. This planning effort has been well coordinated and is expected to improve ground-water management in the State of Maine significantly (Maine State Planning Office, 1986).

\section{SELECTED REFERENCES}

Adamik, J.T., 1984, Present and proposed ground water program for Maine: U.S. Geological Survey Water-Resources Investigations Report 84-4235, 43 p.

Caswell, W.B., 1978, Ground water handbook for the State of Maine: Augusta, Maine Geological Survey, 145 p.

Durfor, C.N., and Becker, Edith, 1964, Public water supplies of the 100 largest cities in the United States, 1962: U.S. Geological Survey WaterSupply Paper 1812, 364 p.

Garrett, Peter, 1986, Threats to ground water in Maine: Maine Department of Environmental Protection and Maine Department of Human Services, 1 plate.

Gay, F.B., and Frimpter, M.H., 1985, Distribution of polychlorinated biphenyls in the Housatonic River, Massachusetts: U.S. Geological Survey Water-Supply Paper 2266, 26 p.

Hess, C.T., Norton, S.A., Brutsaert, W.F., Casparius, R.E., Coombs, E.G. and Hess, A.L., 1979, Radon-222 in potable water supplies in Mainethe geology, hydrology, physics and health effects: Land and Water Resources Center, University of Maine at Orono, 119 p.

Lanctot, E.M., 1985, Radon in the domestic environment and its relationship to cancer-An epidemiological study: Maine Geological Survey Open-File Report 85-88, 39 p.

Maine State Planning Office, 1986, Land and Water Resources Council, 1985 annual report and 1986-1987 statement of priorities: Maine State Planning Office, $36 \mathrm{p}$.

Moreau, Marcel, 1983, Are you pouring oil into the ground: Maine Department of Environmental Protection, EnvironNews, v. 9, no. 11, p. 4-5.

National Council on Radiation Protection and Measurements, 1984, Evaluation of occupational and environmental exposures to radon and radon daughters in the United States: [National Council on Radiation Protection and Measurements,] Report 78, p. 96-112.

National Governors Association, 1985, Areas closed or restricted because of toxic contamination: The Agency for Toxic Substances and Disease Registry, 250 p. 
Prescott, G.C., Jr., 1973, Records of selected wells, springs, and test holes in the southern Washington County area: U.S. Geological Survey Open-File Report, $40 \mathrm{p}$.

Scudder, Jean, and Anderson, Norman, 1986, Petroleum contamination of Maine's drinking water wells: Maine Department of Human Services, Bureau of Health, 8 p.

Tepper, D.H., 1980, Hydrogeologic setting and geochemistry of residual periglacial Pleistocene seawater in wells in Maine: Orono University of Maine, unpublished M.S. thesis, 126 p.

Tolman, A.L., 1986, First annual report-pesticides in ground water study: Maine Geological Survey Open-File Report 86-13, 21 p.

Tolman, A.L., Tepper, D.H., Prescott, G.C., Jr., and Gammon, S.O., 1983, Hydrologeology of significant sand and gravel aquifersNorthern York and Southern Cumberland Counties, Maine: Maine Geological Survey, 4 plates.

U.S. Department of Defense, 1986, Status of the Department of Installation Restoration Program-Information paper: Washington, D.C., U.S. Department of Defense, Office of the Assistant Secretary of Defense (Aquisition and Logistics), Environmental Policy Directorate, February, $35 \mathrm{p}$.

U.S. Environmental Protection Agency, 1976, National interim primary drinking water regulations: Office of Water Supply EPA-570/9-76-003, $159 \mathrm{p}$. 1986a, Maximum contaminant levels (subpart B of part 141, national interim primary drinking-water regulations): U.S. Code of Federal Regulations, Title 40, Parts 100 to 149, revised as of July 1, 1986, p. 524-528.

1986b, Secondary maximum contaminant levels (section 143.3 of part 143, national secondary drinking-water regulations): U.S. Code of Federal Regulations, Title 40, Parts 100 to 149, revised as of July 1, 1986, p. $587-590$.

1986c, Amendment to National Oil and Hazardous Substances Contingency Plan; national priorities list, final rule and proposed rule: Federal Register, v. 51, no. 111, June 10, 1986, p. 21053-21112. 1986d, Quality criteria for water 1986: Office of regulations and standards, Washington, D.C., EPA 440/5-86-001.

1986e, Radon reduction methods-A homeowner's guide: Research and Development OPA-86-005, 24 p.

U.S. Environmental Protection Agency and U.S. Department of Health and Human Services, 1986, A citizen's guide to radon-What is it and what to do about it: Office of Air Radiation OPA-86-004, 16 p.

U.S. Geological Survey, 1985, National water summary 1984-Hydrologic events, selected water-quality trends, and ground-water resources: U.S. Geological Survey Water-Supply Paper 2275, 467 p.

Prepared by T.J. Maloney, U.S. Geological Survey; radon discussion in "Crystalline-Bedrock Aquifers" part of "Background Water Quality" section by E.M. Lanctot, Maine Department of Human Services.

FOR ADDITIONAL INFORMATION: Chief, Maine Office, U.S. Geological Survey, 26 Ganneston Drive, Augusta, ME 04330 


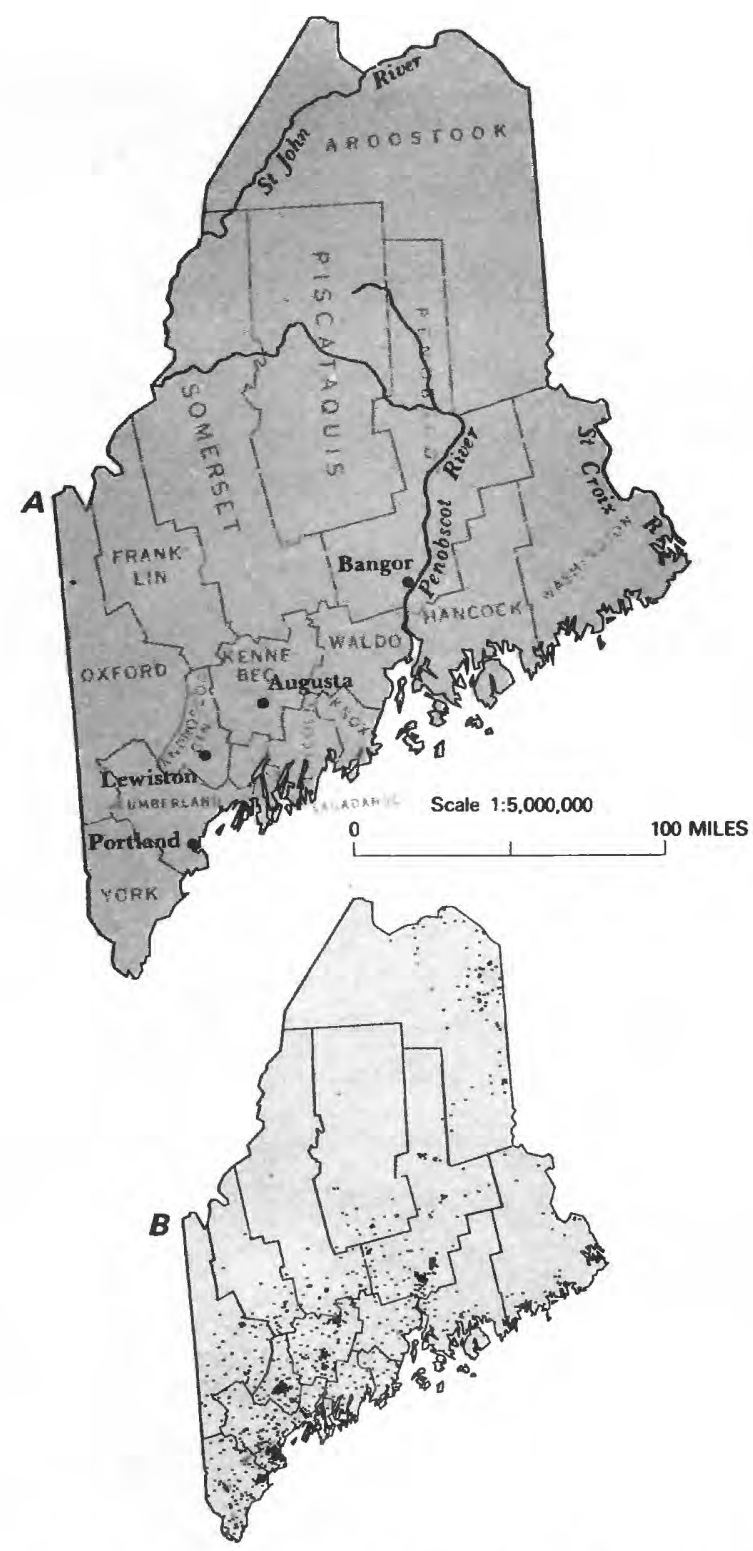

Figure 1. Selected geographic features and 1985 population distribution in Maine. A, Counties, selected cities, and major drainages. $B$, Population distribution, 1985; each dot on the map represents 1,000 people. ISources: B. Data from the U.S. Bureau of the Census 1980 decennial census files, adjusted to the 1985 U.S. Bureau of the Census data for county populations.) 


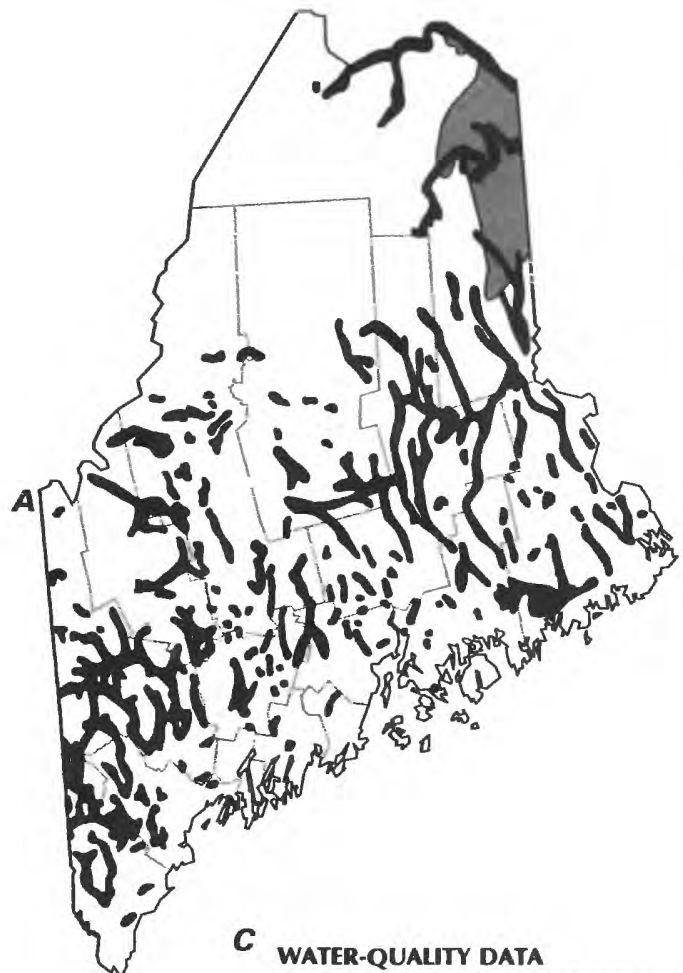

C WATER-QUaLITY DATA

Percentile - Percentage of analyses equal to or less than indicated values

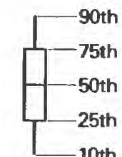

National drinking-water standards Maximum permissible contaminant level (primary)

Maximum recommended contaminant level (secondary)

Maximum recommended contaminan level (health advisory)

Reporting limit

Minimum reporting level with analytical method used
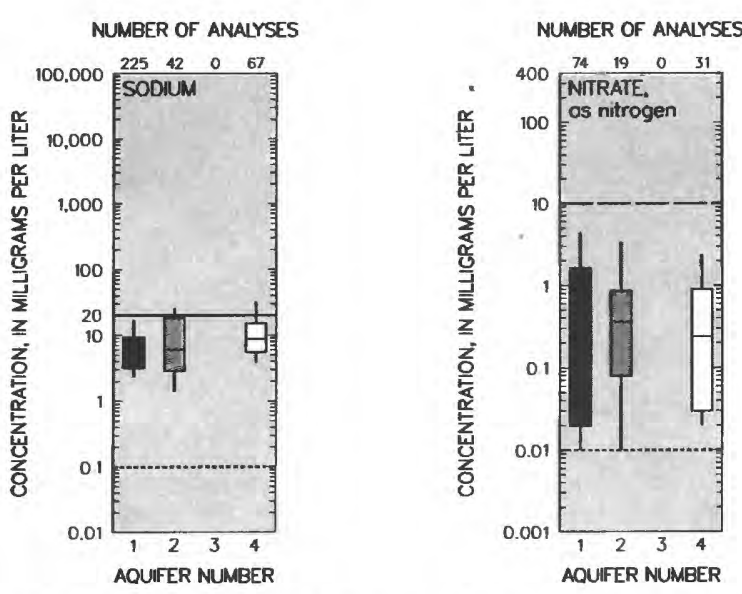
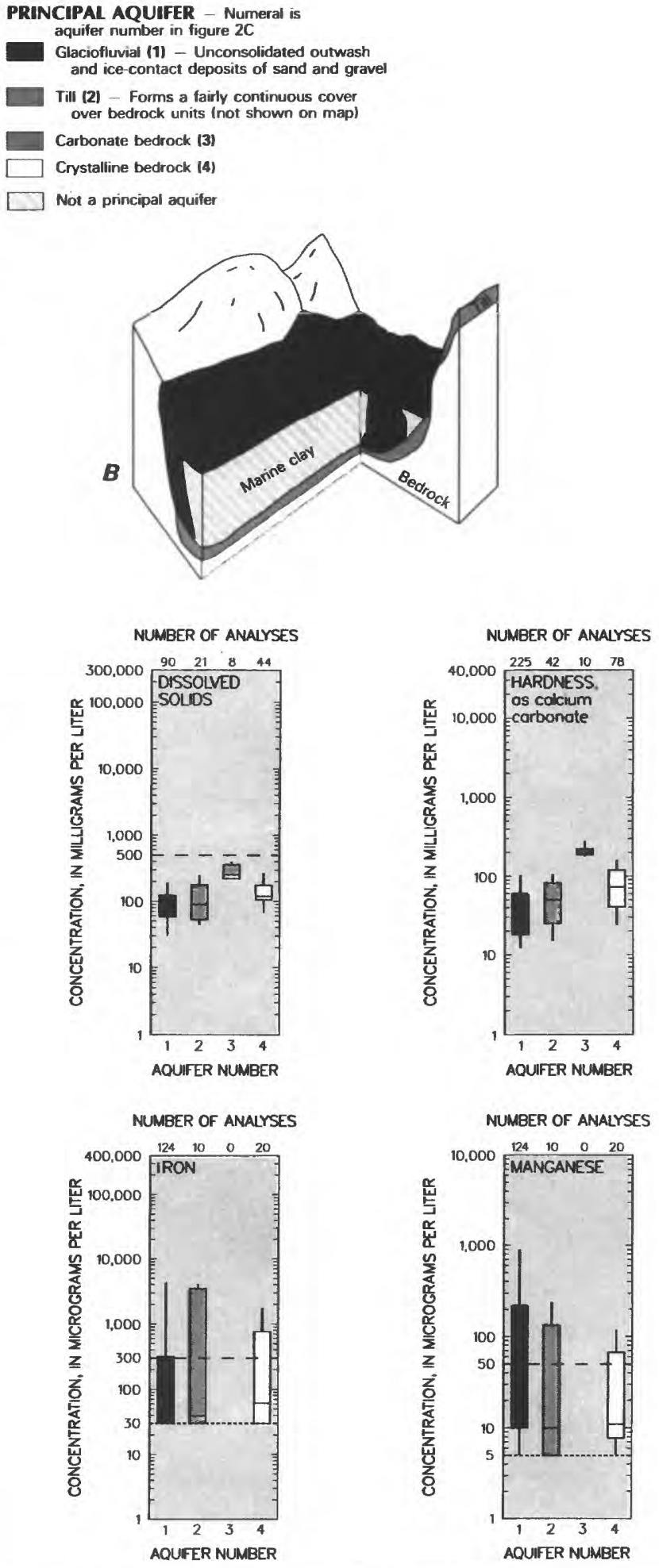

Figure 2. Principal aquifers and related water-quality data in Maine. A, Principal aquifers. $B$, Generalized block diagram. $C$, Selected water-quality constituents and properties, as of 1960-85. (Sources: A. Modified from Adamik, 1984. B. Complied by T.J. Maloney from U.S. Geological Survey files. C. Analyses complied from U.S. Geological Survey files; national drinking-water standards from U.S. Environmental Protection Agency, 1986 a,b.) 


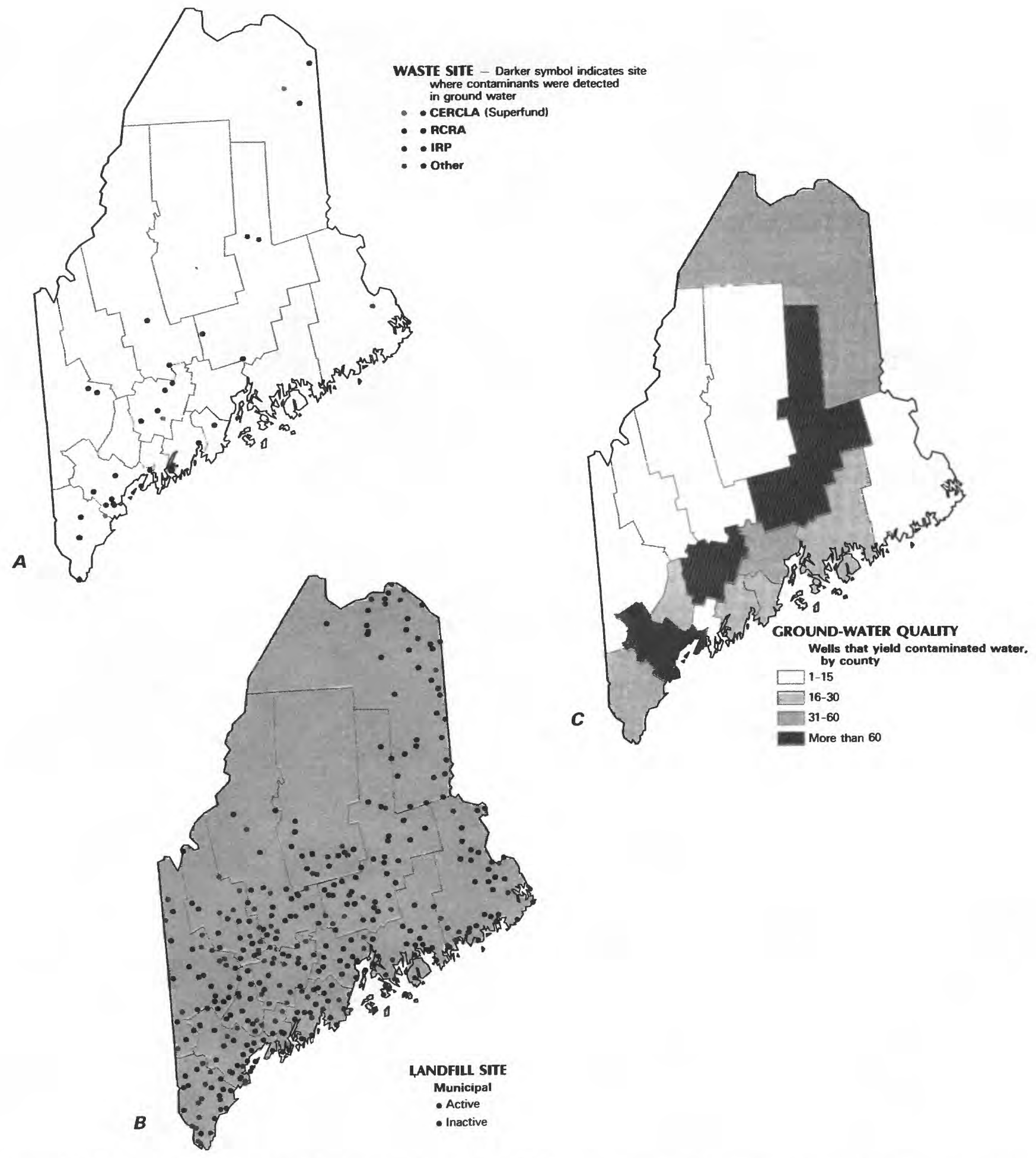

Figure 3. Selected waste sites and ground-water-quality information in Maine. A, Comprehensive Environmental Response, Compensation, and Liability Action (CERCLA) sites; Resource Conservation and Recovery Act (RCRA) sites; Department of Defense Installation Restoration Program (IRP) sites; and other selected waste sites, as of 1985. B, Distribution of wells that yield contaminated water, as of 1985, C. Municipal landfills, as of 1985. (Sources: $A$, Maine Department of Environmental Protection Bureau of Hazardous Materials Control files: $B$, Maine Department of Environmental Protection, Bureau of Water Quality Control files; National Governors Association, 1985; Scudder and Anderson, 1986; and U.S. Department of Defense, 1986. C. Maine Department of Environmental Protection, Bureau of Land Quality Control files.) 


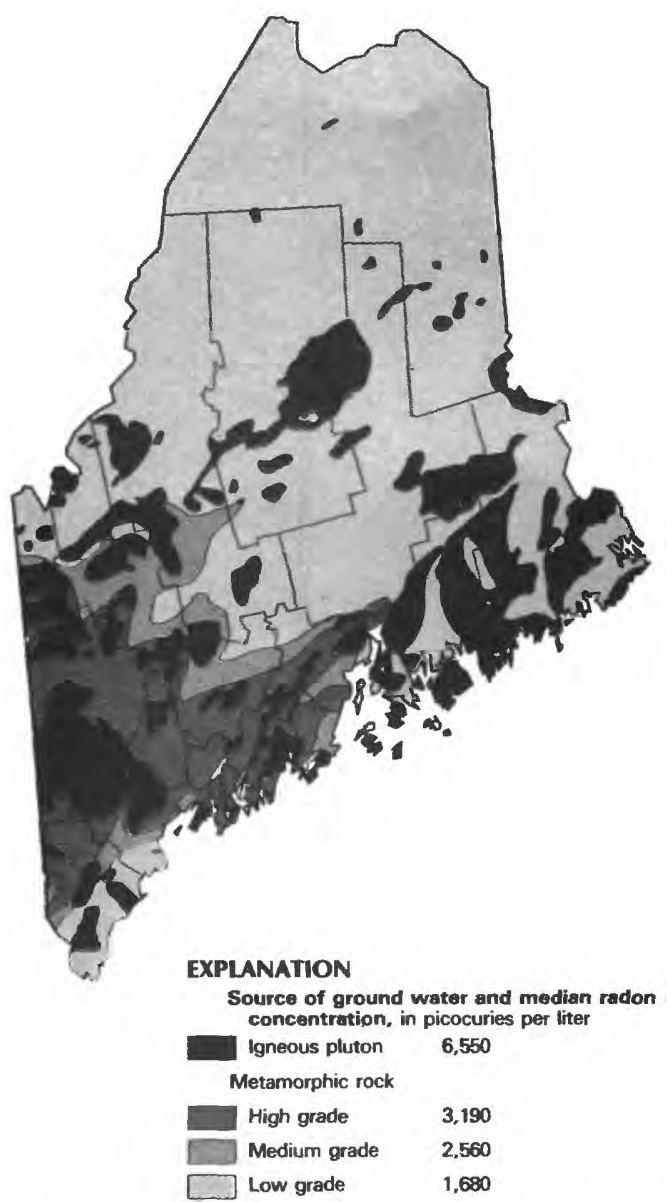

Figure 4. Median radon concentration in water from bedrock and geographic distribution of bedrock types in Maine. (Source: Lanctot, 1985.) 